\title{
Rеsearch автісl: : Effect of different sowing dates on expression of resistance to Helicoverpa armigera in different genotypes of chickpea across four plantings using diet incorporation assay under laboratory conditions
}

Article Chronicle :

Received :

12.07.2017;

Accepted :

25.07.2017

KEY WoRds: Chickpea, Climate, Helicoverpa armigera, Host plant resistance, Diet incorporation assay
SUMMARY : It is difficult to compare genotypic resistance to insects across seasons and locations because of the variation in the onset and severity of insect infestation. Therefore, in this study, we used artificial diet incorporation assays for evaluating chickpea genotypes for resistance to Helicoverpa armigera (L.) across sowing dates. The larval weight was more in insects reared on the crop sown in November than in insects reared on the crop sown in December. Pupal weight was greater on the crop sown in October than on the crop sown in December. Pupation, adult emergence and fecundity were high, whereas larval period was shorter on the crop sown in January, There were no significant differences in survival and development of $H$. armigera across sowing dates. The pupal weight and fecundity were greater, and larval period was shorter on ICC 3137 , contributing to its susceptibility to H. armigera. On ICCV 10, the pupal weight was lower in the crop sown in October, but similar to that on ICC 3137 in the January sown crop, which is susceptible. Different genotypes behaved differently across sowing dates, suggesting differential effect of climatic factors on expression of resistance to $H$. armigera.

How to cite this article : Pavani, T., Babu, T. Ramesh, Sridevi, D., Radhika, K. and Sharma, H.C. (2017). Effect of different sowing dates on expression of resistance to Helicoverpa armigera in different genotypes of chickpea across four plantings using diet incorporation assay under laboratory conditions. Agric. Update, 12(TECHSEAR-

2) : 538-546; DOI: 10.15740/HAS/AU/12.TECHSEAR(2)2017/538-546.

\author{
T. PAVANI, T. RAMESH BABU, D. SRIDEVI, K. RADHIKA AND \\ H.C. SHARMA
}

Author for correspondence :

\section{T. PAVANI}

Professor Jayashankar

Telangana State

Agricultural University

Rajendranagar,

HYDERABAD

(TELANGANA) INDIA

Email:pavani.ento09@

gmail.com

See end of the article for authors' affiliations 